\title{
NADH Dehydrogenase Subunit-2 237 Leu/Met Polymorphism Influences the Association of Coffee Consumption with Serum Chloride Levels in Male Japanese Health Checkup Examinees: An Exploratory Cross-Sectional Analysis
}

\author{
Akatsuki Kokaze ${ }^{1, *}$, Mamoru Ishikawa ${ }^{2,3}$, Naomi Matsunaga ${ }^{2}$, Kanae Karita ${ }^{2}$, Masao Yoshida ${ }^{2}$, \\ Hirotaka Ochiai ${ }^{1}$, Takako Shirasawa ${ }^{1}$, Takahiko Yoshimoto ${ }^{1}$, Akira Minoura ${ }^{1}{ }^{10}$, \\ Kosuke Oikawa ${ }^{1}$, Masao Satoh ${ }^{4}$, Hiromi Hoshino ${ }^{1}$ and Yutaka Takashima ${ }^{2}$ \\ 1 Department of Hygiene, Public Health and Preventive Medicine, Showa University School of Medicine, \\ 1-5-8 Hatanodai, Shinagawa-ku, Tokyo 142-8555, Japan; h-ochiai@med.showa-u.ac.jp (H.O.); \\ shirasawa@med.showa-u.ac.jp (T.S.); yoshimotot@med.showa-u.ac.jp (T.Y.); \\ minoaki@med.showa-u.ac.jp (A.M.); k-oikawa@med.showa-u.ac.jp (K.O.); \\ hhiromi@med.showa-u.ac.jp (H.H.) \\ 2 Department of Public Health, Kyorin University School of Medicine, 6-20-2 Shinkawa, Mitaka-shi, \\ Tokyo 181-8611, Japan; ishikawa-m@genkiplaze.or.jp (M.I.); naomim@ks.kyorin-u.ac.jp (N.M.); \\ kanae@ks.kyorin-u.ac.jp (K.K.); yohhy@ks.kyorin-u.ac.jp (M.Y.); yutakat@kyorin-u.ac.jp (Y.T.) \\ 3 Mito Red Cross Hospital, 3-12-48 Sannomaru, Mito-shi, Ibaraki 310-0011, Japan \\ 4 School of Medical Technology and Health, Faculty of Health and Medical Care, Saitama Medical University, \\ 1397-1 Yamane, Hidaka-shi, Saitama 350-1241, Japan; satoma@saitama-med.ac.jp \\ * Correspondence: akokaze@med.showa-u.ac.jp; Tel.: +81-(3)3784-8133; Fax: +81-(3)3784-7733
}

Received: 6 August 2018; Accepted: 19 September 2018; Published: 20 September 2018 updates

\begin{abstract}
Background: Nicotinamide adenine dinucleotide (NADH) dehydrogenase subunit-2 237 leucine/methionine (ND2-237 Leu/Met) polymorphism has been shown to modify the association of coffee consumption with the risk of hypertension, dyslipidemia, and abnormal glucose tolerance, and low serum chloride levels have been shown to be associated with all-cause and cardiovascular disease mortality. Therefore, the purpose of the present study was to investigate whether ND2-237 Leu/Met polymorphism influences the association of coffee consumption with serum chloride levels in male Japanese health checkup examinees. Methods: From among individuals visiting the hospital for a regular medical checkup, 402 men (mean age \pm standard deviation, $53.9 \pm 7.8$ years) were selected for inclusion in the study. After ND2-237 Leu/Met genotyping, we conducted an exploratory cross-sectional study to examine the combined association of ND2-237 Leu/Met polymorphism and coffee consumption with serum electrolyte levels. Results: After adjusting for age, body mass index, habitual smoking, alcohol consumption, green tea consumption, and antihypertensive medication, coffee consumption significantly increased serum chloride levels ( $p$ for trend $=0.001$ ) in men with the ND2-237Leu genotype. After these adjustments, the odds ratios (ORs) for low levels of serum chloride, defined as $<100 \mathrm{mEq} / \mathrm{L}$, were found to be dependent on coffee consumption ( $p$ for trend = 0.001). In addition, the OR for low levels of serum chloride was significantly lower in men with the ND2-237Leu genotype who consumed $\geq 4$ compared with $<1$ cup of coffee per day (OR $=0.096,95 \%$ confidence interval $=0.010-0.934 ; p=0.044$ ). However, neither serum chloride levels nor risk of low levels of serum chloride appeared to be dependent on coffee consumption. Conclusions: The results suggest that ND2-237 Leu/Met polymorphism modifies the association of coffee consumption with serum chloride levels in middle-aged Japanese men.
\end{abstract}


Keywords: cardiovascular disease; coffee consumption; gene-diet interaction; longevity; NADH dehydrogenase; polymorphism; serum chloride levels

\section{Background}

Coffee intake has been shown to be a favorable health behavior [1-3], and habitual consumption (3-4 cups per day) is more likely to benefit than to harm health [3]. Several recent meta-analyses of prospective studies have reported finding an inverse relationship between habitual coffee consumption and both all-cause [3-6] and cardiovascular disease (CVD) [4,5] mortality. In addition, Rodríguez-Artalejo and López-García reported that habitual consumption of 3-5 cups of coffee per day reduces the risk of CVD by $15 \%$, and that habitual consumption of $>3-5$ cups per day does not elevate the risk of CVD [7].

A population-based cohort study reported finding an association between lower serum chloride levels and both all-cause and CVD mortality [8]. That epidemiological study found that the risk ratio for CVD mortality associated with low serum chloride levels was equivalent to or higher than that observed for well-known risk factors of CVD, including hypertension, diabetes, and habitual smoking [8]. Furthermore, low levels of serum chloride have been reported to be associated with increased mortality and risk of CVD in patients with pre-dialysis chronic kidney disease [9], and serum chloride levels have been shown to be negatively associated with mortality in patients with a history of heart failure $[10,11]$. By contrast, in a large-scale follow-up study involving hypertensive adults, a $1 \mathrm{mEq} / \mathrm{L}$ increase in serum chloride levels was found to reduce all-cause mortality by $1.5 \%$ after adjusting for confounding factors [12].

Nicotinamide adenine dinucleotide (NADH) dehydrogenase subunit-2 237 leucine/methionine (ND2-237 Leu/Met) polymorphism has been reported to be associated with longevity in the Japanese population [13]. The frequency of the ND2-237Met genotype has been found to be substantially higher in Japanese centenarians compared with the general Japanese population [13], and individuals with the ND2-237Met genotype have been shown to be less likely than those with the ND2-237Leu genotype to develop lifestyle-related diseases [14-18].

ND2-237 Leu/Met polymorphism has been reported to modify the effect of coffee consumption on the risks of hypertension [19], glucose tolerance abnormality [20], dyslipidemia [21], liver damage [22], and anemia [23]. We previously reported that serum chloride levels were significantly lower in obese men with the ND2-237Met genotype than in those with the ND2-237Leu genotype [24]. However, to our knowledge, no studies have been conducted to investigate the joint association of ND2-237 Leu/Met polymorphism and coffee consumption with serum chloride levels.

Therefore, the purpose of the present exploratory cross-sectional study was to investigate whether ND2-237 Leu/Met polymorphism modifies the association of coffee consumption with serum chloride levels in male Japanese health checkup examinees.

\section{Subjects and Methods}

\subsection{Study Participants}

The study participants were recruited from among individuals visiting the Mito Red Cross Hospital for a regular medical checkup between August 1999 and August 2000. This study was conducted in accordance with the Declaration of Helsinki. The Ethics Committee of Kyorin University School of Medicine approved the study protocol. Written informed consent was obtained from all 602 volunteers before participation. Because of the insufficient number of women available for categorization into groups based on the ND2-237 Leu/Met genotype and coffee consumption, females were excluded, as were males with unclear or incomplete data. Finally, 402 Japanese men (mean age \pm standard deviation, $53.9 \pm 7.8$ years) were included in the analysis. 


\subsection{Data Collection}

\subsubsection{Clinical Measurements}

The participants' anthropometric, biophysical, and biochemical data were obtained from the results of regular medical checkups. Serum electrolyte levels-namely serum sodium, chloride, potassium, or calcium levels-were determined using an auto-analyzer (HITACHI 7600-110S; Hitachi High Technology Corp., Tokyo, Japan). Body mass index (BMI) was calculated as weight (kg) divided by the square of height $(\mathrm{m})$. Information on antihypertensive treatment was derived from the participants' health records.

\subsubsection{Self-Administered Questionnaire}

A survey regarding coffee intake, habitual smoking, alcohol consumption, and green tea intake was conducted on the participants via a self-administered questionnaire. Similar to previous reports [19-23], coffee consumption was categorized based on the number of cups of coffee consumed per day $(<1,1-3$, and $\geq 4$ cups). Habitual smoking was categorized as non- or ex-smokers and current smokers. Alcohol consumption was categorized based on drinking frequency (daily drinkers; occasional drinkers [those who drink several times per week or month]; and non- or ex-drinkers). Green tea consumption was categorized based on the number of cups of green tea consumed per day $(\leq 1,2-4$, and $\geq 5$ cups).

\subsection{Genotyping}

ND2-237 genotyping methods have been described previously [23]. Briefly, DNA was extracted from white blood cells. ND2-237 Leu/Met genotype was determined using the polymerase chain reaction-restriction fragment length polymorphism test. The absence or presence of an $A l u \mathrm{I}$ site was designated as ND2-237Met or ND2-237Leu, respectively.

\subsection{Statistical Analyses}

All statistical analyses were performed using SAS statistical software (version 9.2 for Windows; SAS Institute, Inc., Cary, NC, USA). Multiple logistic regression analysis was conducted to calculate odds ratios (ORs) for the risk of low levels of serum chloride. In accordance with previous epidemiological studies [8,12], low levels of serum chloride were defined as $<100 \mathrm{mEq} / \mathrm{L}$. For the multiple logistic regression analysis and analysis of covariance, habitual smoking (non- or ex-smokers $=0$, current smokers $=1$ ), alcohol consumption (non- or ex-drinkers $=0$, occasional drinkers $=1$, daily drinkers $=2$ ), green tea consumption ( $\leq 1$ cup per day $=1,2-4$ cups per day $=2, \geq 5$ cups per day $=3$ ) and antihypertensive treatment (not receiving antihypertensive treatment $=0$, receiving antihypertensive treatment $=1$ ) were numerically coded. Two-tailed $p$ values $<0.05$ were considered statistically significant.

\section{Results}

No statistically significant differences in serum electrolyte levels—namely serum sodium, chloride, potassium, or calcium levels-were observed between the ND2-237Leu and ND2-237Met genotypes (Table 1).

A significant positive association was observed between coffee consumption and serum chloride levels in the men with the ND2-237Leu genotype ( $p$ for trend $=0.001$ ) (Table 2). Moreover, serum chloride levels were significantly higher in the participants who consumed $\geq 4$ compared with $<1$ or $1-3$ cups of coffee per day ( $p=0.001$ and $p=0.026$, respectively). After adjusting for age, BMI, habitual smoking, alcohol consumption, green tea consumption, and antihypertensive medication, a significant positive association was found between coffee consumption and serum chloride levels ( $p$ for trend $=0.002$ ). In addition, serum chloride levels were significantly higher in the participants 
who consumed $\geq 4$ compared with $<1$ cup of coffee per day $(p=0.010)$. Moreover, a significant positive association was observed between coffee consumption and serum sodium levels in men with the ND2-237Leu genotype ( $p$ for trend $=0.033$ ); a significant positive association was also found between coffee consumption and serum sodium levels ( $p$ for trend $=0.044$ ). By contrast, no statistically significant association was observed between coffee consumption and serum electrolyte levels in the men with the ND2-237Met genotype.

Table 1. Clinical characteristics of the study participants by ND2-237 Leu/Met genotype.

\begin{tabular}{|c|c|c|c|}
\hline & ND2-237Leu & ND2-237Met & $p$ Value \\
\hline & $N=245$ & $N=157$ & \\
\hline Age (years) * & $54.4(7.8)$ & $53.2(7.8)$ & 0.142 \\
\hline Systolic blood pressure $(\mathrm{mmHg}) *$ & $125.8(15.8)$ & $125.7(14.1)$ & 0.934 \\
\hline Diastolic blood pressure $(\mathrm{mmHg})^{* *}$ welch & $73.9(10.6)$ & $73.7(9.1)$ & 0.817 \\
\hline Low-density lipoprotein cholesterol $(\mathrm{mg} / \mathrm{dL})$ * & $121.3(34.4)$ & $118.0(30.8)$ & 0.319 \\
\hline Uric acid $(\mathrm{mg} / \mathrm{dL})$ * & $5.94(1.24)$ & $5.94(1.22)$ & 0.970 \\
\hline Serum sodium $(\mathrm{mEq} / \mathrm{L}) *$ & $140.3(2.0)$ & $140.1(1.9)$ & 0.200 \\
\hline Serum chloride $(\mathrm{mEq} / \mathrm{L}) *$ & $101.3(2.5)$ & $100.8(2.2)$ & 0.062 \\
\hline Serum potassium $(\mathrm{mEq} / \mathrm{L}) *$ & $4.19(0.28)$ & $4.18(0.26)$ & 0.712 \\
\hline Serum calcium $(\mathrm{mEq} / \mathrm{L}) *$ & $9.33(0.37)$ & $9.38(0.38)$ & 0.180 \\
\hline Coffee consumption $(<1$ cup per day $/ 1-3$ cups per day/ $\geq 4$ cups per day) $(\%) * * * *$ & $44.5 / 46.2 / 9.3$ & $36.3 / 51.6 / 12.1$ & 0.237 \\
\hline
\end{tabular}

Age, body mass index, systolic blood pressure, diastolic blood pressure, low-density lipoprotein cholesterol, high-density lipoprotein cholesterol, uric acid, serum sodium, serum chloride, serum potassium, serum calcium are expressed as means (standard deviation). Triglyceride is expressed as the median (interquartile range). * Student's $t$-test, ${ }^{* *}$ Welch's $t$-test, ${ }^{* * *}$ Mann-Whitney test, ${ }^{* * * *}$ chi-square test. All $p$ values depict significant differences between ND2-237Leu and ND2-237Met.

Table 2. Serum electrolyte levels by coffee consumption status and ND2-237 Leu/Met genotype.

\begin{tabular}{|c|c|c|c|c|}
\hline & \multicolumn{3}{|c|}{ Coffee Consumption } & \multirow[t]{2}{*}{$p$ for Trend } \\
\hline & $<1$ Cup Per Day & 1-3 Cups Per Day & $\geq 4$ Cups Per Day & \\
\hline ND2-237Leu & $N=109$ & $N=113$ & $N=23$ & \\
\hline Serum sodium levels (mEq/L) & $140.1(0.2)$ & $140.4(0.2)$ & $141.2(0.4)$ & 0.033 \\
\hline Serum sodium levels $(\mathrm{mEq} / \mathrm{L})^{\dagger}$ & $140.1(0.2)$ & $140.5(0.2)$ & $141.1(0.4)$ & 0.044 \\
\hline Serum chloride levels (mEq/L) & $100.9(0.2)$ & $101.4(0.2)$ & $102.9(0.5)^{* * * * * *}$ & 0.001 \\
\hline Serum chloride levels $(\mathrm{mEq} / \mathrm{L})^{\dagger}$ & $100.7(0.3)$ & $101.4(0.3)$ & $102.4(0.5) *$ & 0.002 \\
\hline Serum potassium levels (mEq/L) & $4.19(0.03)$ & $4.19(0.03)$ & $4.20(0.05)$ & 0.904 \\
\hline Serum potassium levels $(\mathrm{mEq} / \mathrm{L})^{\dagger}$ & $4.18(0.03)$ & $4.20(0.03)$ & $4.22(0.06)$ & 0.439 \\
\hline Serum calcium levels (mEq/L) & $9.33(0.04)$ & $9.33(0.04)$ & $9.32(0.08)$ & 0.867 \\
\hline Serum calcium levels $(\mathrm{mEq} / \mathrm{L})^{\dagger}$ & $9.40(0.04)$ & $9.35(0.04)$ & $9.33(0.08)$ & 0.306 \\
\hline ND2-237Met & $N=57$ & $N=81$ & $N=19$ & \\
\hline Serum sodium levels (mEq/L) & $140.1(0.2)$ & $140.1(0.2)$ & $139.8(0.4)$ & 0.679 \\
\hline Serum sodium levels $(\mathrm{mEq} / \mathrm{L})^{\dagger}$ & $140.7(0.3)$ & $140.8(0.3)$ & $140.5(0.5)$ & 0.700 \\
\hline Serum chloride levels (mEq/L) & $100.8(0.3)$ & $100.9(0.2)$ & $100.8(0.5)$ & 0.935 \\
\hline Serum chloride levels $(\mathrm{mEq} / \mathrm{L})^{\dagger}$ & $101.3(0.4)$ & $101.2(0.3)$ & $101.3(0.5)$ & 0.965 \\
\hline Serum potassium levels (mEq/L) & $4.17(0.03)$ & $4.18(0.03)$ & $4.18(0.06)$ & 0.905 \\
\hline Serum potassium levels $(\mathrm{mEq} / \mathrm{L})^{\dagger}$ & $4.14(0.05)$ & $4.15(0.04)$ & $4.16(0.07)$ & 0.836 \\
\hline Serum calcium levels (mEq/L) & $9.39(0.05)$ & $9.40(0.04)$ & $9.30(0.09)$ & 0.507 \\
\hline Serum calcium levels $(\mathrm{mEq} / \mathrm{L})^{\dagger}$ & $9.41(0.07)$ & $9.39(0.06)$ & $9.24(0.10)$ & 0.175 \\
\hline
\end{tabular}

${ }^{+}$Serum sodium levels, ${ }^{\dagger}$ serum chloride levels, ${ }^{\dagger}$ serum potassium levels, and ${ }^{\dagger}$ serum calcium levels are expressed as least-square means (standard error) adjusted for age, body mass index, alcohol consumption, habitual smoking, green tea consumption, and antihypertensive medication. The Bonferroni correction for multiple comparisons was applied; ${ }^{*} p<0.05,{ }^{* *} p<0.005$ vs. $<1$ cup of coffee per day, ${ }^{* * *} p<0.05$ vs. $1-3$ cups of coffee per day.

A significant negative association was observed between coffee consumption and the risk of low levels of serum chloride among men with the ND2-237Leu genotype ( $p$ for trend $=0.032$ ) (Table 3). Moreover, the $O R$ for low levels of serum chloride was significantly lower among men with the 
ND2-237Leu genotype who consumed $\geq 4$ compared with $<1$ cup of coffee per day ( $O R=0.125,95 \%$ confidence interval $[\mathrm{CI}]=0.016-0.973 ; p=0.047$ ). After adjusting for age, BMI, habitual smoking, alcohol consumption, green tea consumption, and antihypertensive medication, the risk of low levels of serum chloride was found to be dependent on coffee consumption ( $p$ for trend $=0.028$ ). In addition, the $O R$ for low levels of serum chloride was found to be significantly lower for men with the ND2-237Leu genotype who consumed $\geq 4$ compared with $<1$ cup of coffee per day ( $O R=0.096$, $95 \% \mathrm{CI}=0.010-0.934 ; p=0.044)$. However, the association between the ND2-237Met genotype and the risk of low levels of serum chloride did not appear to be statistically dependent on the amount of daily coffee consumption.

Table 3. Odds ratios (ORs) and 95\% confidence intervals (CIs) for low levels of serum chloride (serum chloride levels $<100 \mathrm{mEq} / \mathrm{L}$ ) by ND2-237 Leu/Met genotype and coffee consumption.

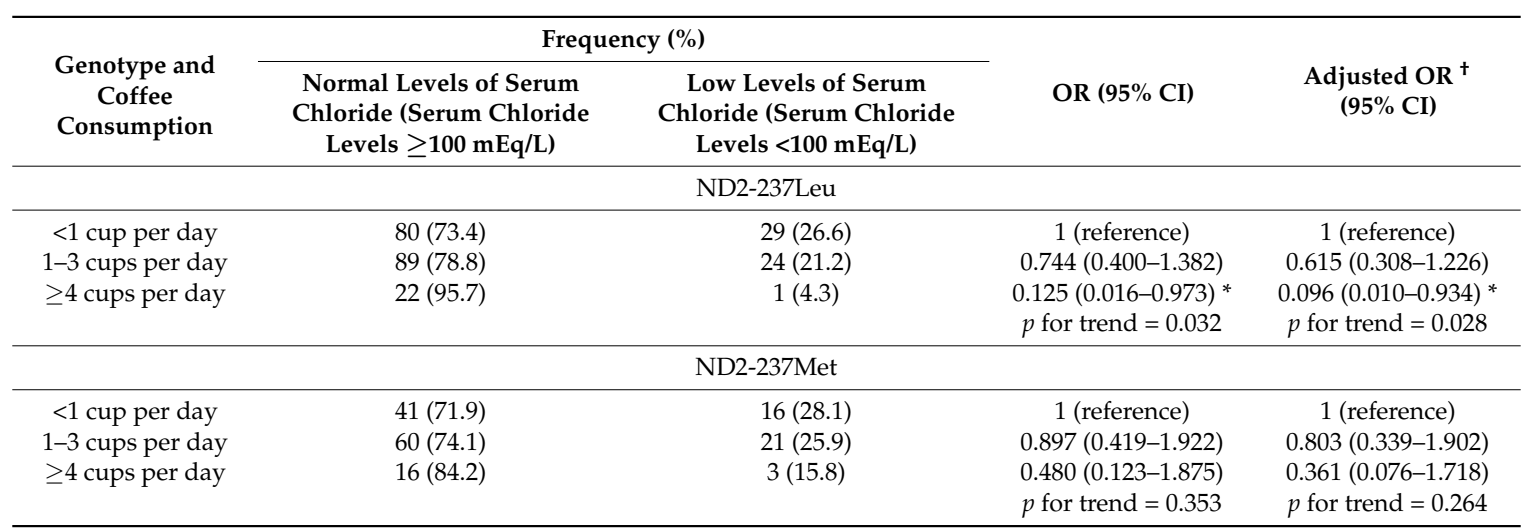

${ }^{\dagger}$ OR adjusted for age, body mass index, habitual alcohol consumption, habitual smoking, green tea consumption, and antihypertensive medication. ${ }^{*} p<0.05$.

\section{Discussion}

Although somewhat limited by the small sample size, the results of the present study suggest that ND2-237 Leu/Met polymorphism and coffee consumption exert a joint association with serum chloride levels in middle-age male Japanese health checkup examinees; namely, serum chloride levels were positively associated with the amount of daily coffee consumption in men with the ND2-237Leu genotype. Moreover, the risk of low levels of serum chloride, which has been shown to be associated with a higher risk of CVD and mortality [8-12], was significantly lower in men with the ND2-237Leu genotype who consumed $\geq 4$ compared with $<1$ cup of coffee per day. However, coffee consumption did not appear to affect serum chloride levels in men with the ND2-237Met genotype.

In regard to the role of the interplay between caffeine and mitochondria in the cardiovascular system, Ale-Agha, et al. recently established experimentally that caffeine acting jointly with mitochondrial cyclin-dependent kinase inhibitor 1B exerts protective effects against CVD [25]. However, although likely related to biochemical differences between ND2-237Leu and ND2-237Met in response to some compounds in coffee, the physiological mechanisms underlying the joint association of ND2-237 Leu/Met polymorphism and coffee consumption with serum chloride levels remains unknown. NADH dehydrogenase is known as a major site of the generation of reactive oxygen species (ROS) in mitochondria; it is also known itself to be a target of attack by ROS [26]. Some animal experiments have demonstrated that ND2-237Met protects NADH dehydrogenase from ROS attack and/or suppresses ROS production [27,28]. Moreover, coffee consumption has been shown to exert antioxidant potential in humans [29]. The results of our previous research suggest that moderate coffee intake exerts antioxidant effects in men with the ND2-237Leu but not the ND2-237Met genotype $[19,20,22]$. To elucidate the mechanisms underlying the joint association of ND2-237 Leu/Met polymorphism and coffee consumption with serum chloride levels, further biophysical and biochemical investigations are needed. 
Previous cross-sectional studies have reported finding an interactive association of ND2-237 Leu/Met polymorphism and coffee consumption with the risks of hypertension [19], glucose tolerance abnormality [20], dyslipidemia [21], liver damage [22], and erythrocytic parameters [23]. The risk of hypertension was significantly lower in men with the ND2-237Leu genotype who consumed $\geq 2$ compared with $\leq 1$ cup of coffee per day [19], and that of glucose tolerance abnormality was also significantly lower in those who consumed $\geq 4$ compared with $<1$ cup of coffee per day [20]. Consequently, the risk of abnormally elevated levels of serum liver enzymes was significantly lower in men who consumed $\geq 3$ compared with $<1$ cup of coffee per day [22]. However, the risk of anemia was significantly higher in those who consumed $\geq 4$ compared with $<1$ cup of coffee per day [23]. Meanwhile, the risk of dyslipidemia was significantly higher among men with the ND2-237Met genotype who consumed $\geq 1$ compared with $<1$ cup of coffee per day [21]. Taken together, other than the risk of anemia, moderate levels of coffee intake appear to be more beneficial for health in men with the ND2-237Leu compared with the ND2-237Met genotype.

Although the focus of the present study was on serum chloride levels, serum sodium levels were also significantly and positively associated with coffee consumption in men with the ND2-237Leu genotype. In addition, in a population-based cohort study, De Bacquer, et al. reported finding a remarkably positive association between serum chloride and serum sodium levels [8]. In patients with acute decompensated heart failure, compared with that of serum chloride levels, the prognostic value of serum sodium levels was diminished [10]. Moreover, in patients with post-myocardial infarction accompanied by systolic dysfunction and heart failure, low levels of serum chloride were found to be associated with CVD mortality accompanied by low levels of serum sodium [30]. Recently, a large-scale follow-up study reported finding an association between low serum sodium levels and an increased risk of CVD mortality [31]; therefore, serum sodium levels may affect the pathophysiology of serum chloride levels for CVD. However, to verify whether serum chloride levels act jointly with serum sodium levels in regard to CVD in the general population, further epidemiological studies are needed.

A potential contradiction may exist in relation to these findings. Although low serum chloride levels have been shown to be associated with an increased risk of both all-cause and CVD mortality [8-12], the results of our previous study showed that serum chloride levels were significantly lower in men who had the ND2-237Met genotype-who have been reported to have a genetic tendency toward longevity [13] and resistance against life-threatening diseases [14-18] — compared with those with the ND2-237Leu genotype [24]. Therefore, the genetic advantage of having the ND2-237Met genotype may surpass the physiological disadvantage of having low serum chloride levels.

The present study did have several important limitations. First, the data were collected 18 years ago. Second, the sample size was relatively small. Third, the participants consisted of only men. Fourth, only a single population was analyzed; to prevent errors in genetic epidemiological studies, several independent data sets need to be analyzed. Fifth, although cross-sectional studies can suggest causal associations, they cannot prove valid causality. To overcome this limitation, a follow-up study involving a larger study sample that includes multiple populations is needed. Sixth, we did not obtain any data on salt intake or other dietary factors. Although no significant associations have been found between serum chloride levels and dietary sodium intake [32], higher sodium intake has been found to be a risk factor for CVD in Japan [33]. Potential correlations between additional dietary factors and coffee consumption have been reported [34]. Therefore, a food frequency questionnaire survey will be required in future studies. Finally, we based the categorization of habitual coffee consumption on the number of cups consumed per day. Whether any interaction exists between ND2-237 Leu/Met polymorphism and levels of caffeine, chlorogenic acids, or other unknown compounds in coffee on serum chloride levels remains unclear and therefore warrants further investigation.

\section{Conclusions}

The results of the present exploratory cross-sectional analysis suggest a joint association of ND2-237 Leu/Met polymorphism and coffee consumption with serum chloride levels among 
male Japanese health checkup examinees. For men with the ND2-237Leu genotype, higher coffee consumption may reduce the risk of low levels of serum chloride. Therefore, daily coffee intake is recommended for men with the ND2-237Leu genotype to reduce the risk of CVD. To the best of our knowledge, this is the first report of the effects of gene-diet interaction on serum chloride levels. These findings may contribute to individualized prevention strategies for CVD.

Author Contributions: A.K. designed the study, carried out the epidemiological survey, carried out genotyping, analyzed the data, and drafted the manuscript; M.I. collected the samples; K.K. and M.Y. carried out the epidemiological survey; N.M. assisted with genotyping; H.O., T.S., T.Y., A.M., K.O., M.S., and H.H. assisted in the data analysis and the interpretation of the results; Y.T. designed the study and carried out the epidemiological survey. All authors have read and approved the final manuscript.

Funding: This study was supported in part by Grants-in-Aid from the Ministry of Education, Culture, Sports, Science and Technology of Japan (No. 14570355, No. 18590572, No. 23500859, and No. 26350908) and the Chiyoda Mutual Life Foundation.

Conflicts of Interest: The authors declare no conflict of interest.

\section{References}

1. Cano-Marquina, A.; Tarin, J.J.; Cano, A. The impact of coffee on health. Maturitas 2013, 75, 7-21. [CrossRef] [PubMed]

2. Cornelis, M.C. Coffee intake. Prog. Mol. Biol. Transl. Sci. 2012, 108, 293-322. [CrossRef] [PubMed]

3. Poole, R.; Kennedy, O.J.; Roderick, P.; Fallowfield, J.A.; Hayes, P.C.; Parkes, J. Coffee comsumption and health: Umbrella review of meta-analyses of multiple health outcomes. BMJ 2017, 358, j5024. [CrossRef] [PubMed]

4. Malerba, S.; Turati, F.; Galeone, C.; Pelucchi, C.; Verga, F.; La Vecchia, C.; Tavani, A. A meta-analysis of prospective studies of coffee consumption and mortality for all causes, cancers and cardiovascular diseases. Eur. J. Epidemiol. 2013, 28, 527-539. [CrossRef] [PubMed]

5. Crippa, A.; Discacciati, A.; Larsson, S.C.; Wolk, A.; Orsini, N. Coffee consumption and mortality from all causes, cardiovascular disease, and cancer: A dose-response meta-analysis. Am. J. Epidemiol. 2014, 180, 763-775. [CrossRef] [PubMed]

6. Je, Y.; Giovannucci, E. Coffee consumption and total mortality: A meta-analysis of twenty prospective cohort studies. Br. J. Nutr. 2014, 111, 1162-1173. [CrossRef] [PubMed]

7. Rodríguez-Artalejo, F.; López-García, E. Coffee consumption and cardiovascular disease: A condensed review of epidemiological evidence and mechanisms. J. Agric. Food Chem. 2018, 66, 5257-5263. [CrossRef] [PubMed]

8. De Bacquer, D.; De Backer, G.; De Buyzere, M.; Kornitzer, M. Is low serum chloride level a risk factor for cardiovascular mortality? J. Cardiovasc. Risk 1998, 5, 177-184. [CrossRef] [PubMed]

9. Mandai, S.; Kanda, E.; Iimori, S.; Naito, S.; Noda, Y.; Kikuchi, H.; Akazawa, M.; Oi, K.; Toda, T.; Sohara, E.; et al. Association of serum chloride level with mortality and cardiovascular events in chronic kidney disease: The CKD-ROUTE study. Clin. Exp. Nephrol. 2017, 21, 104-111. [CrossRef] [PubMed]

10. Grodin, J.L.; Simon, J.; Hachamovitch, R.; Wu, Y.; Jackson, G.; Halkar, M.; Starling, R.C.; Testani, J.M.; Tang, W.H. Prognostic role of serum chloride levels in acute decompensated heart failure. J. Am. Coll. Cardiol. 2015, 66, 659-666. [CrossRef] [PubMed]

11. Zhang, Y.; Peng, R.; Li, X.; Yu, J.; Chen, X.; Zhou, Z. Serum chloride as a novel marker for adding prognostic information of mortality in chronic heart failure. Clin. Chim. Acta 2018, 483, 112-118. [CrossRef] [PubMed]

12. McCallum, L.; Jeemon, P.; Hastie, C.E.; Patel, R.K.; Williamson, C.; Redzuan, A.M.; Dawson, J.; Sloan, W.; Muir, S.; Morrison, D.; et al. Serum chloride is an independent predictor of mortality in hypertensive patients. Hypertension 2013, 62, 836-843. [CrossRef] [PubMed]

13. Tanaka, M.; Gong, J.S.; Zhang, J.; Yoneda, M.; Yagi, K. Mitochondrial genotype associated with longevity. Lancet 1998, 351, 185-186. [CrossRef]

14. Kokaze, A.; Ishikawa, M.; Matsunaga, N.; Yoshida, M.; Satoh, M.; Teruya, K.; Masuda, Y.; Honmyo, R.; Uchida, Y.; Takashima, Y. NADH dehydrogenase subunit-2 $237 \mathrm{Leu} /$ Met polymorphism modifies the effects of alcohol consumption on risk for hypertension in middle-aged Japanese men. Hypertens. Res. 2007, 30, 213-218. [CrossRef] [PubMed] 
15. Wang, D.; Taniyama, M.; Suzuki, Y.; Katagiri, T.; Ban, Y. Association of the mitochondrial DNA 5178A/C polymorphism with maternal inheritance and onset of type 2 diabetes in Japanese patients. Exp. Clin. Endocrinol. Diabetes 2001, 109, 361-364. [CrossRef] [PubMed]

16. Mukae, S.; Aoki, S.; Itoh, S.; Sato, R.; Nishio, K.; Iwata, T.; Katagiri, T. Mitochondrial 5178A/C genotype is associated with acute myocardial infarction. Circ. J. 2003, 67, 16-20. [CrossRef] [PubMed]

17. Takagi, K.; Yamada, Y.; Gong, J.S.; Sone, T.; Yokota, M.; Tanaka, M. Association of a 5178C $\rightarrow$ A (Leu237Met) polymorphism in the mitochondrial DNA with a low prevalence of myocardial infarction in Japanese individuals. Atherosclerosis 2004, 175, 281-286. [CrossRef] [PubMed]

18. Ohkubo, R.; Nakagawa, M.; Ikeda, K.; Kodama, T.; Arimura, K.; Akiba, S.; Saito, M.; Ookatsu, Y.; Atsuchi, Y.; Yamano, Y.; et al. Cerebrovascular disorders and genetic polymorphisms: Mitochondrial DNA5178C is predominant in cerebrovascular disorders. J. Neurol. Sci. 2002, 198, 31-35. [CrossRef]

19. Kokaze, A.; Ishikawa, M.; Matsunaga, N.; Karita, K.; Yoshida, M.; Ohtsu, T.; Shirasawa, T.; Sekii, H.; Ito, T.; Kawamoto, T.; et al. NADH dehydrogenase subunit-2 237 Leu/Met polymorphism modulates the effects of coffee consumption on the risk of hypertension in middle-aged Japanese men. J. Epidemiol. 2009, 19, 231-236. [CrossRef] [PubMed]

20. Kokaze, A.; Ishikawa, M.; Matsunaga, N.; Karita, K.; Yoshida, M.; Ohtsu, T.; Shirasawa, T.; Haseba, Y.; Satoh, M.; Teruya, K.; et al. Longevity-associated mitochondrial DNA 5178 C/A polymorphism modifies the effect of coffee consumption on glucose tolerance in middle-aged Japanese men. In Handbook on Longevity: Genetics, Diet and Disease; Bentely, J.V., Keller, M.A., Eds.; Nova Science Publishers: New York, NY, USA, 2009; pp. 139-160.

21. Kokaze, A.; Ishikawa, M.; Matsunaga, N.; Karita, K.; Yoshida, M.; Shimada, N.; Ohtsu, T.; Shirasawa, T.; Ochiai, H.; Kawamoto, T.; et al. Combined effect of longevity-associated mitochondrial DNA 5178 C/A polymorphism and coffee consumption on the risk of hyper-LDL cholesterolemia in middle-aged Japanese men. J. Hum. Genet. 2010, 55, 577-581. [CrossRef] [PubMed]

22. Kokaze, A.; Yoshida, M.; Ishikawa, M.; Matsunaga, N.; Karita, K.; Ochiai, H.; Shirasawa, T.; Nanri, H.; Mitsui, K.; Hoshino, H.; et al. Mitochondrial DNA 5178 C/A polymorphism modulates the effects of coffee consumption on elevated levels of serum liver enzymes in male Japanese health check-up examinees: An exploratory cross-sectional study. J. Physiol. Anthropol. 2016, 35, 15. [CrossRef] [PubMed]

23. Kokaze, A.; Ishikawa, M.; Matsunaga, N.; Karita, K.; Yoshida, M.; Ohtsu, T.; Ochiai, H.; Shirasawa, T.; Nanri, H.; Saga, N.; et al. Longevity-associated mitochondrial DNA 5178 C/A polymorphism modulates the effects of coffee consumption on erythrocytic parameters in Japanese men: An exploratory cross-sectional analysis. J. Physiol. Anthropol. 2014, 33, 37. [CrossRef] [PubMed]

24. Kokaze, A.; Ishikawa, M.; Matsunaga, N.; Yoshida, M.; Makita, R.; Satoh, M.; Teruya, K.; Sekiguchi, K.; Masuda, Y.; Harada, M.; et al. Longevity-associated NADH dehydrogenase subunit-2 polymorphism and serum electrolyte levels in middle-aged obese Japanese men. Mech. Ageing Dev. 2005, 126, 705-709. [CrossRef] [PubMed]

25. Ale-Agha, N.; Goy, C.; Jakobs, P.; Spyridopoulos, I.; Gonnissen, S.; Dyballa-Rukes, N.; Aufenvenne, K.; von Ameln, F.; Zurek, M.; Spannbrucker, T.; et al. CDKN1B/p27 is localized in mitochondria and improves respiration-dependent processes in the cardiovascular system-New mode of action for caffeine. PLoS Biol. 2018, 16, e2004408. [CrossRef] [PubMed]

26. Madamanchi, N.R.; Runge, M.S. Mitochondrial dysfunction in atherosclerosis. Circ. Res. 2007, 100, 460-473. [CrossRef] [PubMed]

27. Gusdon, A.M.; Votyakova, T.V.; Mathews, C.E. mt-Nd2a suppresses reactive oxygen species production by mitochondrial complexes I. and III. J. Biol. Chem. 2008, 283, 10690-10697. [CrossRef] [PubMed]

28. Stadtman, E.R.; Moskovitz, J.; Berlett, B.S.; Levine, R.L. Cyclic oxidation and reduction of protein methionine residues is an important antioxidant mechanism. Mol. Cell. Biochem. 2002, 234, 3-9. [CrossRef] [PubMed]

29. Ishizaka, Y.; Yamakado, M.; Toda, A.; Tani, M.; Ishizaka, N. Relationship between coffee consumption, oxidant status, and antioxidant potential in the Japanese general population. Clin. Chem. Lab. Med. 2013, 51, 1951-1959. [CrossRef] [PubMed]

30. Ferreira, J.P.; Girerd, N.; Duarte, K.; Coiro, S.; McMurray, J.J.; Dargie, H.J.; Pitt, B.; Dickstein, K.; Testani, J.M.; Zannad, F.; et al. Serum chloride and sodium interplay in patients with acute myocardial infarction and heart failure with reduced ejection fraction: An analysis from the high-risk myocardial infarction database initiative. Circ. Heart Fail. 2017, 10, e003500. [CrossRef] [PubMed] 
31. He, X.; Liu, C.; Chen, Y.; He, J.; Dong, Y. Risk of cardiovascular mortality associated with serum sodium and chloride in the general population. Can. J. Cardiol. 2018, 34, 999-1003. [CrossRef] [PubMed]

32. Van Berge-Landry, H.; James, G.D. Serum electrolyte, serum protein, serum fat and renal responses to a dietary sodium challenge: Allostasis and allostatic load. Ann. Hum. Biol. 2004, 31, 477-487. [CrossRef] [PubMed]

33. Iso, H. Lifestyle and cardiovascular disease in Japan. J. Atheroscler. Thromb. 2011, 18, 83-88. [CrossRef] [PubMed]

34. Solvoll, K.; Selmer, R.; Løken, E.B.; Foss, O.P.; Trygg, K. Coffee, dietary habits, and serum cholesterol among men and women 35-49 years of age. Am. J. Epidemiol. 1989, 129, 1277-1288. [CrossRef] [PubMed]

2018 by the authors. Licensee MDPI, Basel, Switzerland. This article is an open access article distributed under the terms and conditions of the Creative Commons Attribution (CC BY) license (http://creativecommons.org/licenses/by/4.0/). 